\title{
Attributes for assessing the environmental quality of riparian zones
}

\author{
Marta González del Tánago \& Diego García de Jalón \\ E.T.S. Ingenieros de Montes, Universidad Politécnica de Madrid \\ Ciudad Universitaria, 28040- Madrid.marta.gtanago@upm.es,diego.gjalon@upm.es
}

\begin{abstract}
Seven attributes of riparian systems are proposed to be considered for assessing the ecological status of riparian zones. They can be easily evaluated by taking into consideration some features of the structure and functioning of riverine systems, largely determined by their hydromorphological dynamics.

The structure of riparian zones could be characterized by the longitudinal continuity of vegetation, the lateral dimensions (width) of the channel containing natural riparian vegetation and the composition and structure of riparian vegetation communities. These attributes basically define the morphology of riparian areas, reflecting a static view of the river. They also define the spatial dimensions where riparian functions take place, indicating the possibilities of carrying on riparian restoration activities at short time scales.

The functioning of riparian systems may be assessed considering the ratio of natural woody species regeneration, bank conditions, lateral connectivity and permeability of riparian soils. These attributes indicate the temporal behaviour of riparian zones, that is showed in a more dynamic or video view of the river. They are more related to the potential of achieving riparian restoration at longer time scales, representing key elements to guarantee the self-maintenance of fluvial processes and riparian biodiversity. The aforementioned attributes provide a framework to assess the ecological status of riparian zones, and offer a minimum checklist of criteria to evaluate strategies for restoring and preserving river ecosystems.
\end{abstract}

Keywords: Riparian zones, ecological status, environmental assessment, river restoration.

\section{RESUMEN}

El estado ecológico de las riberas fluviales puede quedar caracterizado a través de siete atributos. Dichos atributos pueden ser fácilmente evaluados teniendo en cuenta diferentes aspectos de la estructura y del funcionamiento de los sistemas riparios, los cuales están fuertemente determinados por la dinámica hidromorfológica fluvial.

La estructura de las riberas queda caracterizada por la continuidad longitudinal de la vegetación, las dimensiones laterales (anchura) del espacio fluvial conteniendo vegetación riparia natural y la composición y estructura de las comunidades vegetales riparias. Estos atributos definen básicamente la morfología de las riberas, y quedan reflejados en una visión estática o fotografia del río. A su vez, dichos atributos definen las dimensiones espaciales donde tienen lugar las funciones riparias, e indican las posibilidades de llevar a cabo la restauración fluvial a corto plazo.

El funcionamiento de los sistemas riparios queda reflejado a través de la tasa de regeneración natural de las especies leñosas riparias, la condición de las orillas, la conectividad lateral del cauce con sus riberas y la permeabilidad de los suelos riparios. Estos atributos indican el comportamiento en el tiempo de las riberas, y su evaluación requiere una visión dinámica, reflejada en un vídeo del río. Dichos atributos están más relacionados con las posibilidades de lograr la restauración fluvial a más largo plazo, representando elementos claves para garantizar la sostenibilidad de los procesos fluviales y la biodiversidad de los sistemas riparios.

Los atributos mencionados representan en su conjunto un esquema para evaluar el estado ecológico de las riberas fluviales, y sirven como criterios para evaluar las propuestas de estrategias de restauración y conservación de los ecosistemas fluviales.

Palabras clave: Riberas, estado ecológico, evaluación ambiental, restauración fluvial.

\section{INTRODUCTION}

The interest in the hydrological and ecological functioning of riparian systems has increased considerably in the last decades. This has happened not only because of scientific reasons related to the development of Riverine Landscape Ecology (Tockner et al., 2002), but also as a consequence of riparian areas being one of the main targets in environmentally-sound river manage- 
ment. Nowadays, riparian and floodplain systems are seriously degraded by different human activities, and the scientific understanding of their hydrological and ecological functioning is greatly needed for their restoration.

The scientific knowledge of riparian systems has evolved relatively fast, since the early meetings held in the 1970s (see Johnson \& McCormick, 1978), when riparian zones were first considered to be well-defined landscape features, distinct enough to warrant special consideration (Odum, 1978). Since then, riparian systems have been the main topic of a lot of research and many scientific meetings and publications (e.g., Warren \& Hendrix, 1984; Johnson et al., 1985; Naiman \& Décamps, 1990; Malanson, 1993; Wigington \& Beschta, 2000), and they have been rapidly incorporated in the integrated watershed management approach (e.g., Naiman, 1992; Doppelt et al., 1993; Naiman \& Bilby, 1998). Today, riparian systems are included in nearly all aspects of water management (García de Jalón \& Vizcaíno, 2004; European Declaration for a New Water Culture, 2005) and their restoration is considered an essential step in water resources planning and ecosystem sustainability.

In Europe, the implementation of the Water Framework Directive has promoted the study of riparian zones, since they are included as "quality elements" of the hydromorphological conditions that have to be evaluated in the assessment of the ecological status of water bodies. This requirement of the Water Framework Directive makes having easy and rapid methods to evaluate riparian conditions necessary, in order both to characterise the ecological status of riparian zones and to assist in diagnosing their main problems. Such methods can also provide useful guidelines for proposing restoration strategies.

There are several methods and indexes for assessing the quality and integrity of river ecosystems. The protocols proposed by Barbour et al. (1999), Bjorkland et al. (2001), Ward et al. (2003) and Jansen et al. (2004) are good examples of methods to evaluate the physical and biological elements of the channel and the riparian areas of rivers. The work of Platts et al. (1987) and Winward (2000) are devoted directly to riparian resources.

In Spain, Munné et al. (1998) have proposed the QBR (Biological Quality of the Riparian zones) index to evaluate the ecological quality of riparian habitats in rivers and streams. This index has been frequently used in many studies and reports (González del Tánago et al., 1998, Suárez and Vidal Abarca, 2000), although it has some limitations when applied in some regions (Suárez et al., 2002).

The QBR index place special emphasis on evaluating the quality of the present riparian vegetation in terms of percentage of cover, connectivity with adjacent forest ecosystems, number of native tree species, etc. However, it does not take into account the seasonal and successional dynamics of the vegetation, nor the different natural potential of each river reach according to the geomorphological conditions of the valley or the type of the flow regime. Furthermore, the taxonomic identification of the riparian species is not necessary when applying the QBR, as this index differentiates only between tree and shrub species, and native and non-native species (Munné et al., 2003). This fact makes the QBR not very well suited for evaluating the status of the riparian areas in the context of the Water Framework Directive, where the comparison between the actual species composition and structure of vegetation with those corresponding to the reference conditions should form the basis of the evaluation of the ecological status of each river reach.

In this paper, the principles of a new system to assess the environmental quality of the riparian areas are presented, as an alternative approach of the QBR. This new method takes into consideration seven attributes that are related to the hydrological and ecological functioning of riparian systems, and it attempts to define optimum conditions and their succesive stages of degradation. Further, the analysis of these attributes allows the establishment of the reference condition for each river reach, which is not only very useful for identifying the main causes of 


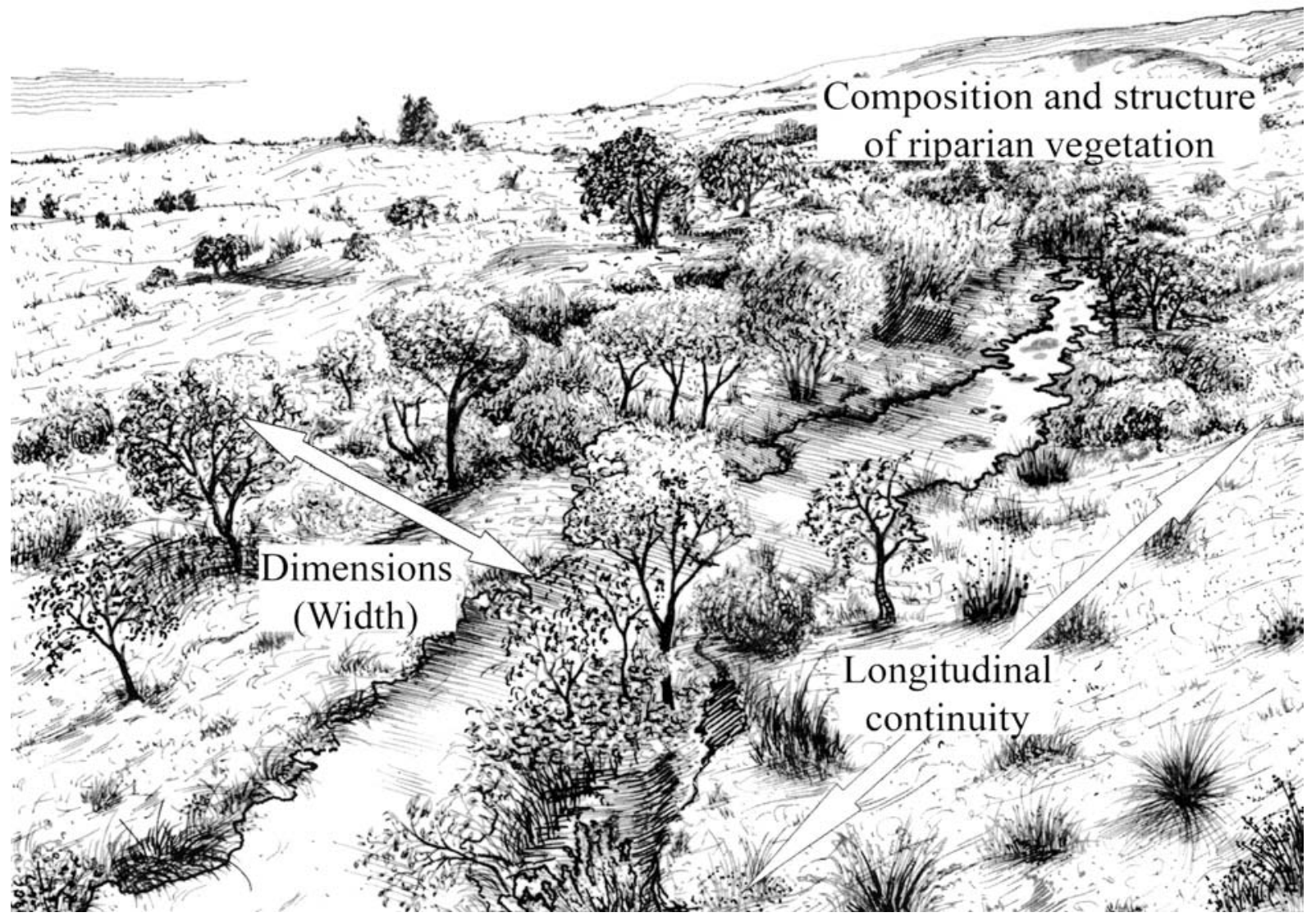

Figure 1. Physical structure attributes of riparian zones. Atributos que caracterizan la estructura física de las zonas riparias.

riparian degradation at different scales, but also for proposing management alternatives to improve and restore the riparian systems.

\section{ATTRIBUTES OF THE HDYROLOGICAL AND ECOLOGICAL FUNCTIONING OF RIPARIAN ZONES}

Seven attributes are proposed as necessary for assessing the ecological status of riparian zones. They can be easily evaluated by analysing several elements of the structure and functioning of riverine systems, which are largely defined by their hydromorphological dynamics. They are briefly outlined here and described in more detail below.

In terms of the "structure" of the riparian zones, we identify three essential components
(Fig. 1). First, the longitudinal continuity of the vegetation is one of the main characteristics of intact river corridors. The existence of continuous vegetated strips along the channel mostly contributes to the control of the flow or movement of water, nutrients, sediment and species through the landscape (Forman \& Godron, 1986). Second, the lateral dimension (width) of the channel and floodplain containing natural riparian vegetation defines the size of the area where hydrological and ecological processes and functions take place, and influences the heterogeneity of the riparian zone. Third, the composition and structure of the riparian vegetation reflects the ecological quality of one of the main riparian elements, and this condition should be evaluated relative to the composition and structure of riparian vegetation defined by the reference conditions for each river reach. 
In terms of the "functioning" of the riparian zones as an integrated element of the river ecosystem, we recognize four elements as the most representative of their hydrological and ecological conditions (Fig. 2). First, the natural woody species regeneration indicates the ability of the present vegetation to maintain successful populations under the current flow regime or riparian area management. Second, bank conditions determine the quality, stability and heterogeneity of physical habitat for many species. Third, the lateral connectivity of riparian zones allows the natural exchange of water, nutrients and sediments between the spatial mosaics of the floodplain and the river channel, which is essential to maintain the riparian biodiversity (Junk, 2005). Fourth, the permeability of riparian soils controls the types of subsurface and groundwater flows and therefore the vertical dimension of the fourdimensional river ecosystem (Ward, 1989).

These seven attributes could be visually evaluated according to several characteristics that can be easily associated to the optimum, good, fair and poor conditions. Taken together, they represent a useful approach to score the ecological status of riparian zones in the context of the Water Framework Directive, helping to identify at the same time the main causes and symptoms of degradation and the general strategies to follow for restoring the riparian zones.

The attributes associated with the "structure" of the riparian areas basically define their morphology, which can be considered as a static or picture (snapshot) view of the river. At the same time, however, these attributes represent the spatial dimensions where the riparian functions take place, and they therefore can be related to the possibilities of doing riparian restoration activities at short time scales.

On the contrary, the attributes related to the "functioning" of the riparian zones define their temporal behaviour and their evaluation requires a more dynamic or video view of the river. These dynamic attributes are more related to the potential of achieving riparian restoration at longer time scales based on time-varying fluvial processes, and they thus represent key elements needed to guarantee the self-sustainability of riparian biodiversity and ecosystem processes.

\section{Longitudinal continuity of natural riparian vegetation (woody species)}

One of the main characteristics of natural corridors is their longitudinal continuity. This continuity creates a central habitat along which the transport of matter, energy and biota takes place (Forman \& Godron, 1986).

In riparian areas, this continuity is essential for maintaining the biodiversity and the functions of the corridor. The riparian zones present elongated shapes with very high edge-to-area ratios, which make them more vulnerable to human impacts, as they generally represent narrow green belts crossing urban-industrial and agricultural areas. Under this condition, the amount of forest edge relative to forest interior is very high, and the maintenance of the longitudinal connectivity is crucial to ensure the opportunities for the migration of plant and animal species inside the corridor, and for the gene flow between populations of tree species (Malanson, 1993; Hughes, 2003).

The level of fragmentation of the riparian vegetation corridor could be an indicator of its degree of degradation or its level of risk for losing certain species that are intolerant to human impacts. Analysing the spatial dynamics of riparian forested patches, Hanson et al. (1990) show a decrease of the number of species when the patches are separated more than $150 \mathrm{~m}$, with significantly less loss of species when patches are closer or maintain their connectivity. Also, bird communities are affected by the increase of the "edge" of the riparian forest, revealing a decrease of richness in nesting species after the fragmentation of riparian forest (Décamps et al., 1987).

Human activities usually reduce the size of riparian zones and their longitudinal connectivity, due to the high value of this land for many purposes. In many cases, the scarcity of riparian vegetation makes the perception of the existence of the river difficult loosing some aesthetic values of the landscape; and this deforestation diminishes the function of nutrient and sediment 


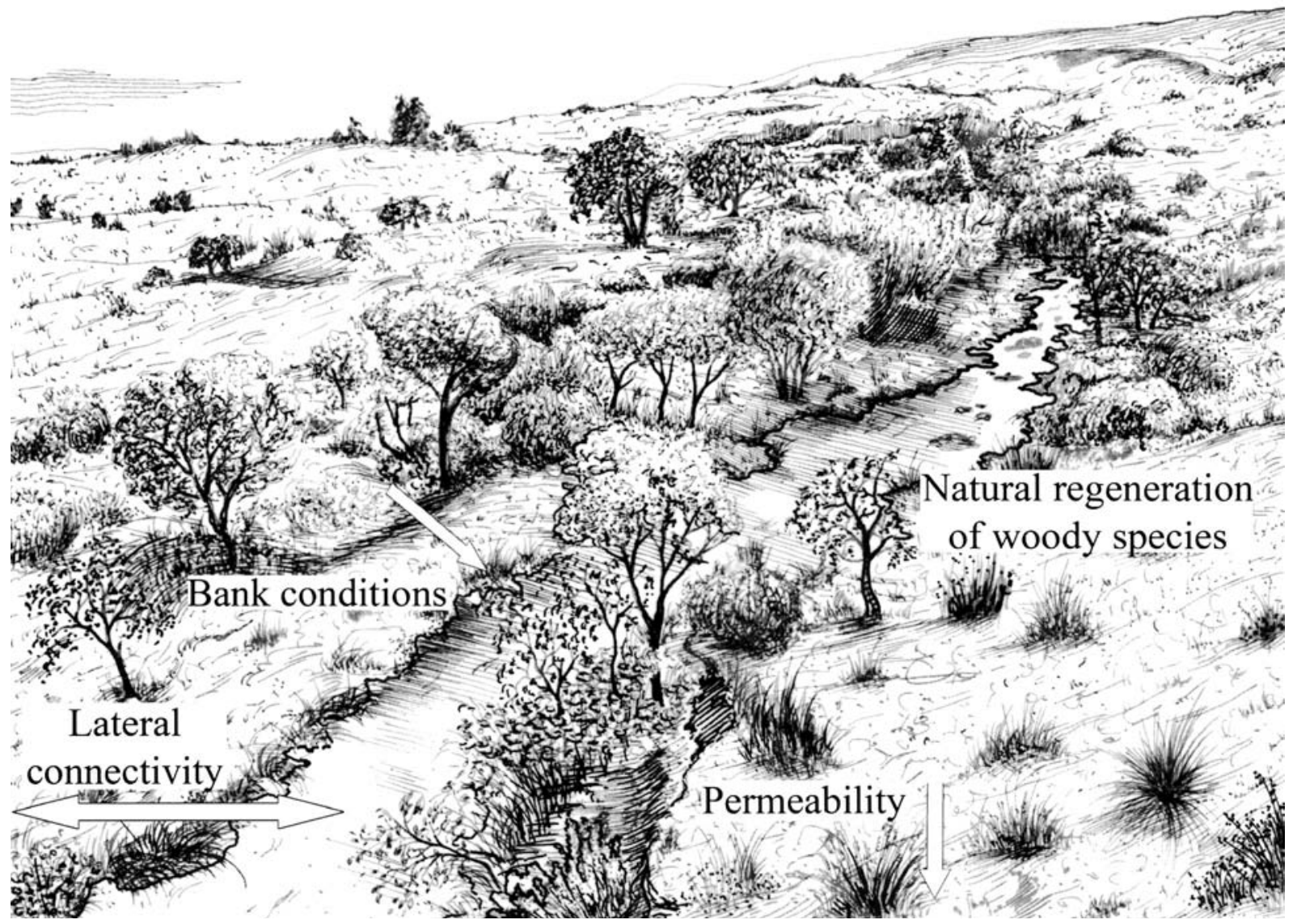

Figure 2. Hydrological and ecological functioning attributes of riparian zones. Atributos que caracterizan el funcionamiento hidrológico y ecológico de las zonas riparias.

filtration from adjacent agricultural lands (Lovell \& Sullivan, 2005).

A good measure of the "longitudinal continuity" of the riparian corridor (inversely related to its fragmentation level) could be the percentage of the longitudinal axis of the riparian zone covered by woody species (trees and shrubs). The vegetation density of the forested patches and the distance between these patches, which is related to the size of the open sites without this woody vegetation, should be also taken into account. The very good ecological status in this case should correspond to a high percentage of the length of the riparian zone (e.g., more than $75 \%$ ) covered by a dense woody riparian vegetation, whereas the very poor ecological status would be indicated by isolated trees or shrubs along the channel cove- ring less than $25 \%$ of the length of the riparian zone, or the absence of woody species and the predominance of the herbaceous communities covering the lateral parts of the river channel.

\section{Lateral dimensions (width) of floodplain with riparian vegetation (woody species and macrophytes)}

This attribute is related to the size of the riparian zone where the hydrological and ecological functions of the riverine landscapes can take place, such as flood energy dissipation, surface water storage, infiltration and groundwater recharge, and interchange of sediments, nutrients and biota from the river channel to the floodplain. These functions occur during floods, when water exceeds the channel and occupies the lateral parts of 
the river, connecting various landscape patches where exchanges of matter and energy are possible (Ward, 1989; Amorós \& Bornette, 2002).

The aim of evaluating this riparian attribute is to know how much space the river has for maintaining flood dynamics, taking into account that the width of the riparian corridors together with their longitudinal connectivity are essential for maintaining their functions and biodiversity (Malanson, 1993). Wider and larger riparian areas would offer more potential to perform these functions and provide more floodplain habitats for many species.

Many authors have tried to estimate the optimum width of the riparian corridor necessary for maximizing species richness, and estimates vary depending on the considered biological communities. As an example, Spackman \& Hughes (1995) found that a much smaller riparian width (between 10 and $30 \mathrm{~m}$ ) was necessary to maintain the $90 \%$ of vegetation species, meanwhile a much wider area (between $75 \mathrm{y}$ $175 \mathrm{~m}$ ) was necessary for having the $90 \%$ of bird species in a study in mid order streams in Vermont (USA). Also a lot of research has been conducted to determine the optimum width of riparian vegetation for retaining nutrients from agricultural lands (Osborne \& Kovacic, 1993; Schultz et al., 1997; Correl, 2005), being one of the most critical variable in the design of bufferstrips to reduce non-point water pollution.

In natural conditions, the width of the riparian corridor depends on the geomorphological conditions of the channel and the valley, together with the size of the river, which changes along the river corridor. In the headwaters of streams, such as high mountainous river reaches, the valleys are $\mathrm{V}$-shaped, relatively confined, and the channels are narrow and steep. The lateral dimension of the channel receiving fluvial influence is relatively small, and the optimum width of the riparian area could be estimated around $5 \mathrm{~m}$, which would correspond to a narrow row of riparian vegetation. As the river goes downstream, its valley generally becomes progresively broader, with gentle relief, and alluvial terraces and floodplains are predominant landforms in the fluvial system, where a much wider riparian forest can exist. In this case, the opti- mum width of the riparian area might be closer to $10-15 \mathrm{~m}$ for the middle reaches or relatively open valleys, and be more than $50 \mathrm{~m}$ for larger rivers in broader and flat valleys.

Taking into account the morphology of the valley and the channel, the optimum riparian corridor width for each river reach, could be estimated and compared with the actual dimensions. According to the results, the quality of the riparian corridor could be evaluated in terms of the amount of available width for the fluvial dynamics. The width of the floodplain containing riparian vegetation is also an indicator of the available space for potential riparian restoration without modifying the present land uses, and should be evaluated separately in each reach, according to its specific river valley morphology and human land use pressures.

\section{Composition and structure of riparian vegetation}

The composition and structure of riparian vegetation vary along the river corridor, due to differences in climatic and geomorphological valley conditions and ecological gradients in the river continuum and network dynamics (Vannotte et al., 1980; Montgomery, 1999; Benda et al., 2004).

Each river reach has different ecological conditions for riparian vegetation development, according to its biogeographic region, altitudinal range or geological condition. Flow regime has also a critical influence on riparian vegetation patterns, leading to a high variability of vegetation characteristics, with a critical influence of environmental factors, such as confluences of tributaries or climatic boundaries, on their longitudinal zonation (Tabacchi et al., 1990) and significant effects of river regulation (Nilsson et al., 2000).

The analysis of species composition and relative abundance of the main woody species of riparian vegetation could help us to evaluate the naturalness of the river reach. Agricultural practices, overgrazing or alteration of the natural flow regime and suppression of fluvial processes are very frequent human-induced river impacts that have caused dramatic changes in 
composition and structure of riparian vegetation. Pettit et al. (2001) have highlighted the strong relationship between floristics, life form structure and population dynamics with stream hydrology. Water diversions also affect the composition and structure of riparian vegetation, especially in arid zones where wetland species that depend on shallow water tables can decline or be replaced by upland species tolerant to drier conditions (Stromberg et al., 1996). Declines in species diversity can also occur due to flood disturbance reduction or temporal and spatial diversity of flood disturbance decrease (Pollock et al., 1998).

The assessment of this riparian attribute should be carried out comparing present conditions with those considered natural or reference for the study river reach. Several indicators can be used, such as height average of native vegetation, shrub density, abundace of nemoral species, absence of exotic or ruderal species, etc. But these features should be accompanied by an analysis of riparian vegetation communities to determine if the present species composition and relative abundance correspond to that considered natural for the study river reach. For example, in temporary or ephemeral streams, the composition and structure of riparian vegetation is characterized by dense shrub formations of drought tolerant species (Tamarix sp., Nerium oleander, Vitex agnus-castus, Securinega tinctoria, etc.), and the presence of native species from other river types such as Salix sp., Populus sp., etc., could indicate flow regime alteration (e.g., water transfers) or agricultural impacts.

In this case, works like those of Lara et al. (1996, 2004), where compostion and relative abundance of riparian species are described for natural or reference conditions for the different river types, are needed to define the optimum conditions for each river reach. Succesive degradation stages can be established from the reference riparian vegetation community, taking into account the decrease of quality of the vegetation corridor in terms of reduced average height and density, number of native species, changes in relative abundances, invasion of species indicating drier conditions, grazing effects, etc.

\section{Natural woody species regeneration}

Natural regeneration of the main riparian species is necessary to ensure the maintenance of the composition and structure of the present riparian forest through time. Human activities can lead to certain conditions under which this natural regeneration is reduced or not possible anymore, promoting some successional trends that differ considerably from those considered natural in the respective area. For this reason, the assessment of the composition and structure of riparian vegetation should be complemented with the analysis of the ratio of the natural woody species regeneration, which could be estimated by the age class distribution of the main species.

Richards et al. (2002) consider the diversity of age structure, which is defined as the frequency distribution of ages of a species in an area or habitat, an indicator of ecological diversity and environmental value of floodplains. In these geomorphologically dynamic environments, flooddriven erosion and deposition processes promote the physical habitat heterogeneity that maintains the age diversity of riparian woody species (Salo et al., 1986; Ward \& Tockner, 2001).

There is a clear evidence that natural regeneration of riparian forest greatly depends on the flood hydrograph, which has been frequently modified by different mechanisms (ZamoraArroyo et al., 2001; Lytle \& Merrit, 2004). Dams, water diversions and flow regulation have disrupted the natural pulse-flood regime, disrupting the natural ecology of riparian corridors (Johnson, 2002). But other humaninduced impacts, such as overgrazing, agricultural practices, fires, and channelization works, also reduce the potential of natural regeneration, by periodically eliminating seedlings, disrupting riparian soil structure, or changing the soil moisture regime because of channel incision after dredging.

Considering that natural woody riparian communities should have a diverse age class structure that reflects the dynamism and hetero- 
geneity of floodplain habitats, we could assume that the optimum condition would correspond to the presence of several age classes (seedlings, saplings, middle-aged and old trees), which would reflect ongoing self-replacement. This age diversity will indicate that current flow regime and riparian management are allowing an adequate amount of recruitment and growth to sustain or recover the woody riparian component. The opposite condition would correspond to the absence of younger elements, and the predominance of mature individuals with frequent mortality of old plants.

In less active floodplains, or in reaches with few open sites where natural seedling establishment can take place, the evaluation of natural regeneration by this age-class diversity should be complemented by taking into account the intensity of the human pressure that may be reducing the potential for natural regeneration. Such pressures could include flow regulation (decrease of flood frequency), agricultural practices (frequency and depth of plowghing, addition of herbicides, frequency and intensity of fires, etc.), intensity of the overgrazing, etc.

\section{Bank conditions}

River banks are key features that influence riparian conditions because they exert significant control on river hydraulic geometry, which itself controls flow and sediment routing and thus physical habitat diversity and channel-floodplain interactions (Stewardson, 2005). Bank length, bank stability and bank undercut are current variables included in the standard fish habitat inventories (Overton et al., 1997), and they also have a deep control upon the establishment, growth and distribution of riparian vegetation (Hupp, 1999).

Bank erosion is a main component of fluvial dynamics. The natural disturbance regime which constitutes this dynamic process is primarly responsible for the habitat mosaic renewal and diversification in floodplains, and for the high level of landscape diversity in river corridors (Ward et al., 2002). The natural and inmediate response to this erosion is the colonization of the new habitats by riparian vegetation, which takes place when these open sites have appropriate soil moisture and flooding conditions for seed germination (Hughes, 2003).

But very often, bank erosion is accelerated by human activities and the newly created sites cannot be colonized by vegetation, due to their instability or their unfavourable soil moisture regime. Severe channel degradation typically removes most of the riparian zone from the influence of fluvial processes for most of the time; this fact reduces the connectivity of the channel with the riparian zone and the ecological value of bank habitats, leading to deterioration of the aquatic ecosystem and the water quality (Hupp, 1999).

Many types of human intervention can cause accelerated bank erosion and retreat, thereby leading to a loss of physical habitat and riparian biodiversity (Brookes, 1988; Gregory, 2002). These include: agricultural practices or overgrazing that degrade or compact soils, flow regime changes that cause large fluctuations of soil bank moisture, and dredging or channelization works that induce channel incision.

There are some field indicators of channel stability that can be used in the assessment of river bank conditions, such as large or frequent eroding cliffs of unconsolidated sediments delivering sediment directly to the channel; slabs, blocks or overhangs indicating scour by fluvial processes; collapse of fence lines, embankments or arboreal vegetation, bare roots, etc. (Sear, 1996). Beyond these, the shape of the wetted perimeter of the channel should be taken into account, to assess the naturalness of river banks. In natural conditions, this perimeter is very sinuous and irregular, and a small water depth exists near the bank, between bed sediments and bankside vegetation. In realigned or modified river banks, after dredging or bank reveting, the perimeter of the water border is much straight and shorter, and water depth near the bank is greater and more uniform.

Taking into account the effect of riparian vegetation on stabilizing river banks (Thorne, 1990), we could propose as optimum conditions when a considerable dimension of the river bank length (e.g., more than $50 \%$ ) is covered by woody spe- 
cies, macrophytes or rocks, there is no evidence of bank instability or human-induced erosion processes, and the water border is irregular with a natural shape. Less favourable conditions should correspond to a smaller ratio of river bank length (less than $50 \%$ ) protected by riparian vegetation or presence of rocks, with presence of instability features in the open spaces, or when the river banks are realigned, as a consequence of bank revetments that have shortened the perimeter of contact between water and channel banks. The poorest conditions in this case should correspond to the reaches where bank protection by vegetation is minimal, and there are indicators of severe bank erosion affecting riparian vegetation establishment. or in cases where channelization works have created hard concrete banks with fixed water borders where dynamic fluvial processes are largely precluded.

\section{Lateral connectivity}

Water level fluctuations in river channels associated with flow regime variability, periodically determine lateral expansions of the water surface inundating the floodplains. This lateral connectivity between the river channel and its floodplain is an essential component of natural fluvial hydrosystems (Ward, 1989; Amorós \& Bornette, 2002). The lateral interactions between main channel and its floodplain are responsible for many biogeochemical and habitat processes that support the biodiversity along river corridors.

The flood pulse is the primary driving force in river-floodplain systems (Junk et al., 1989). Periodic floods inundating floodplains allow exchanges of biota, sediments, organic matter and inorganic nutrients between landscape patches. At the same time, kinetic energy of flooding water is responsible for periodic reshaping of the area, causing erosion and deposition processes, creating new habitats for vegetation recruitment, etc, that determine the physical heterogeneity at different spatial scales (Poole, 2002).

The transfer of sediment, nutrients and biota that takes place by this lateral connectivity is important not only during the flood rise, from the river channel to the floodplain, but also during the flood recession, from the floodplain to the channel. In this case, the release of dissolved organic carbon and nutrients from surface sediments and their transport back into the river channel constitutes an important energy source for aquatic organisms, forming the base of food webs in the lotic ecosystems (Thoms, 2003).

Lateral connectivity of riparian zones could be qualitatively estimated by the frequency of floods that hydrologically link these areas with main channel. In natural conditions, bankfull discharge typically occurs with a recurrence interval of 1.5 - 2 years in humid areas with permanent flow regimes (Dunne \& Leopold, 1978) and with a lower frequency, once in $5-10$ years, in Mediterranean rivers with a much higher flow regime variability (Estrela, 1994). Flows slightly larger than these "bankful" floods should inundate the riparian zones, which occupy a variablewidth floodplain-area according to the frequency and magnitude of flooding.

Human activities change the lateral connectivity of riparian-river systems not only by altering the natural hydrological pattern of floodplain inundation, but also by reducing reactive floodplain surface areas. Flow regulation decreases annual maximum flows and frequency of small to intermediate size floods; land use changes lead to bank elevation (e.g., soil leveling for agriculture irrigation); construction of levees and dykes, or dredging and deepening the river channels, greatly reduce lateral connections of floodplains, with severe implications on carbon and nutrients exchange, reducing the productivity of the entire river system (Thoms, 2003).

Optimum conditions of lateral connectivity could be recognized when the channel banks are low (at bankfull discharge), they are inundated frequently (once between 2-8 years according to the flow regime variability), and there is no restriction for flooding in the adjacent areas close to the channel. Intermediate environmental status could correspond to channel banks elevated by human intervention, riparian zones inundated with a periodicity less than once in 10 years, or when there are restrictions for flooding due to flow regulation, dredging or moderate channel incision. The poorest conditions could be found 
when the banks have been elevated and are not accesible for ordinary (1.5-2 to 8-10 years) floods, the frequency of inundation of riparian zones is less than once in 25-30 years, or where engineering structures or severe channel incision restrict lateral expansion of flood waters.

\section{Permeability of riparian soils}

Riparian soils generally have coarse permeable materials, which come from alluvial processes with succesive deposition events at different channel migration stages (Leopold, 1973). These permeable soils facilitate water infiltration and groundwater recharge during floods, endowing riparian systems with a high water storage capacity. Through these water flows, riparian areas maintain a higher soil moisture content needed by their vegetation, and control the physico-chemical characteristics of water reaching the channel, as stormflow or base flow (Hill, 2000).

Ecologically, these permeable riparian soils play an important role on the ecosystem functioning, enlarging the area where vertical connections between river beds and the hyporheic zone take place, according to geological features and directions of flow fluxes. The river's vertical dimension, which represents the hyporheic zone, is often connected with a permanent groundwater zone, and this zone can provide refuge for many species during floods and droughts and a nursery for benthic invertebrates (Stanford \& Ward, 1993; Ward et al., 1998) and a thermal refuge for fish (Baxter \&. Hauer, 2000). Also the hyporheic zone influences carbon and nutrient dynamics and microbial activities and is thus very important to nutrient transformation and biodiversity in river corridors (Ward, 1989; Malard et al., 2002).

Different human activities alter the surface-subsurface hydrological exchanges in river corridors. Gravel extractions often change significantly the granulometry (sediment size distribution) of the riparian soil horizons, affecting their permeability and soil moisture retention capacity for vegetation establishment. Often the large holes created by sediment extractions are backfilled with unwanted impermeable soils removed from urbanized areas, underground infraestructure construction, etc., thereby dramatically changing the water flows through the hyporheic zone under the riparian areas and even the channel bed. The chemical nature of the backfill can also affects the quality of subsurface flows, in addition to the permeability and flow quantity.

But other human impacts on riparian zones can also alter the vertical dimension of aquatic ecosystems by soil compactation and sealing caused by agricultural practices, overgrazing, road construction, urbanization, etc. These activities reduce or prevent water infiltration, decreasing the opportunities of soil moisture replenishment under low-rain climate conditions, which also occur in many urban areas. Flow regulation and channelization also affect vertical underground water flows by reducing the frequency of floods or by enhancing incision processes that cause the drying of riparian soils.

Evaluating this riparian attribute, the optimum conditions would correspond to natural riparian soils without compacted or sealed areas, and without sediment extractions or alterations of the natural relief. Fair or intermediate conditions would be presented in the cases of presence of paths or roads ocupying some percentage of riparian surface, compacted or sealed areas preventing vegetation regeneration, gravel extractions and changes of natural granulometry, incorporating alloctonous less permeable materials, building debris, and so forth. The poorest conditions in this case would be found when a high percentage of riparian soil has became impermeable, or the soil profile has been changed incorporating imported materials containing salts or harmful chemicals, or when the riparian natural surface drainage has been disrupted by the presence of dykes, soil deposits, rubbish dumps, etc.

\section{APPLICATIONS}

The attributes considered in this paper reveal the main structure and functioning characteristics of riparian systems, and represent useful qualitative criteria for assessing their ecological 
status under current flow regimes and riparian management practices. Furthermore, the analysis of these attributes may help in diagnosing causes and consequences of riparian degradation, as well as identifying restoration strategies and evaluating post-project appraisals.

The systematic analysis of these seven attributes, if extended all over the basin and for several years, and then delineated on appropriate maps, could offer a consistent spatial and temporal information about the locations of the best preserved riparian areas. Further, this information would help identifying the main problems affecting each river reach or watershed, as well as the temporal trends of degradation or recovery.

The analysis of the aforementioned riparian attributes can also help us infering the main pressures that are limiting natural riparian functions, and to define management options for riparian restoration. Restoration or rehabilitation alternatives can be defined more straightforwardly if the main degradation causes are correctly identified and the human pressures that are limiting natural riparian functioning in each river reach are known (González del Tánago, 2004). Very often the causes of riparian degradation are related to disruption of hydrologic regimes, overgrazing or direct conversion to irrigated cropland and urban areas. These disruptions normally provoke loss of lateral and vertical connectivity, channel incision and bank stability, change in native vegetation composition, and natural regeneration, symptons that are directly evaluated by the riparian attributes already reviewed.

These riparian attributes can also serve as succes criteria for post-project appraisals in adaptive management of river restoration. Downs \& Kondolf (2002) emphasize the importance of these post-project appraisals to evaluate the degree to which the proposed objectives have been achieved with the restoration project, and to assess the efficiency of resource investment. These appraisals should be based on systematic data collection, that could be associated in riparian restoration projects with the status of the riparian attributes here discussed.

Also, Palmer et al. (2005) have recently proposed five criteria for ecological success in river restoration, one of which being the measurable improvement of ecological conditions of the river ecosystem. Following this principle, the riparian attributes presented here would provide meaningful indicators with which ecologically successful restoration procedures could be assessed.

\section{AKNOWLEDGEMENTS}

We greatly appreciate the contribution of LeRoy Poff reading and commenting the manuscript, improving significantly its final version. We also thank the assistance of Salvador Rodríguez for his English support. The drawings included in this paper have been made by Martín Oliete.

This paper is a tribute to Dr. Margalef, forever in our hearts as a reference of an excellent person and extraordinary scientist, such an intelligent and wise admirer of Nature.

\section{REFERENCES}

AMOROS, C. \& G. BORNETTE. 2002. Connectivity and biocomplexity in waterbodies of riverine floodplains. Freshwat. Biol., 47(4): 761-776.

BARBOUR, M. T., J. GERRITSEN, B. D. ZINDER \& J. B. STRIBLING. 1999. Rapid bioassessment protocols for use in streams and wadeable rivers: Periphyton, benthic macroinvertebrates and fish. $2^{\text {nd }}$ edition, EPA 841-B-99-002. Washington, D.C. $38 \mathrm{pp}$.

BAXTER, C. V. \& F. R. HAUER. 2000. Geomorphology, hyporheic exchange, and selection of spawning habitat by bull trout (Salvelinus confluentus). Can. J. Fish Aquat. Sci., 57: 1470-1481.

BENDA, L., N. L. POFF, D. MILLAR, T. DUNNE, G. REEVES, G. PESS \& M. POLLOCK. 2004. The Network Dynamics Hypothesis: How Channel Networks structure riverine habitats. BioScience, 54(5): 413-427.

BJORKLAND, R., C. M. PRINGLE \& B. NEWTON. 2001. A stream visual assessment protocol (SVAP) for riparian landowners. Environ. Monit. Assess., 68(2): 99-125.

BROOKES, A. 1988. Channelized Rivers: Perspectives for Environmental Management. John Wiley $\&$ sons, Chichester. 326 pp. 
CORREL, D. L. (in press). Principles of planning and establishment of buffer zones. Ecological Engineering.

DÉCAMPS, H., J. JOACHIM \& J. LAUGA. 1987. The importance for birds of the riparian woodlands within the alluvial corridor of the River Garonne, south west France. Regulated Rivers: Research and Management, 1: 301-316.

DOPPELT, B., M. SCURLOCK, C. FRISSELL \& J. KARR. 1993. Entering the Watershed. Island Press, Washington. 462 pp.

DOWNS, P.W. Y G. M. KONDOLF. 2002. PostProject Appraisals in Adaptive Management or River Channel Restoration. Environ. Manag. 29 (4): 477-496.

DUNNE, T. \& L. B. LEOPOLD. 1978. Water in Environmental Planning. W.H. Freeman \& co, San Francisco. 818 pp.

ESTRELA, T. 1994. Aspectos prácticos de la definición de la máxima crecida ordinaria. Asistencia Técnica para la ordenación de cauces y márgenes inundables, CEDEX 42-493-6-001. Madrid. 49 pp.

EUROPEAN DECLARATION FOR A NEW WATER CULTURA. 2005. Fundación Nueva Cultura del Agua, Zaragoza. 63

FORMAN, R. T. T. \& M. GODRON. 1986. Landscape Ecology. John Wiley \& sons, New York. $619 \mathrm{pp}$.

GARCÍA DE JALÓN, D. \& P. VIZCAÍNO (eds.). 2004. Aquatic Habitats: Analysis \& Restoration. Fifth Internacional Symposium on Ecohydraulics, IAHR Congress Proceedings, Madrid. 1453 pp.

GONZÁLEZ DEL TÁNAGO, M. 2004. Restauración de los ríos: Conceptos, Objetivos y criterios de actuación. In: Congreso de Restauración de Ríos y Humedales. J. Cachón de Mesa \& T. López-Piñeiro (eds.): 15-32. Publ. Cedex, Ministerio de Fomento, Madrid.

GONZÁLEZ DEL TÁNAGO, M.\& N. ANTÓN. 1998. Programa de Protección HidrológicoForestal, Subprograma de Ríos y Riberas. En: Plan Forestal de la Comunidad de Madrid. Consejería de Medio Ambiente y Desarrollo Rural, Madrid. E.T.S. Ingenieros de Montes, $272 \mathrm{pp}$.

GREGORY, K. J. 2002. Urban Channel Adjustments in a Management Context: An Australian Example. Environ. Manag., 29(5): 620-633.

HANSON, J. S., G. P. MALANSON \& M. P. ARMSTRONG. 1990. Modelling the effects of dispersal and landscape fragmentation on forest dynamics. Ecol. Model., 49: 277-296.
HILL, A. R. 2000. Stream Chemistry and Riparian Zones. In: Streams and Ground Waters. J. B. Jones \& P. J. Mulholland (eds.).: 83-110. Academic Press, San Diego.

HUGHES, F. M. R. (ed.). 2003. The Flooded Forest: Guidance for policy makers and river managers in Europe on the restoration of floodplain forests. FLOBAR2, Department of Geography, University of Cambridge, UK. 90 pp.

HUPP, C. R. 1999. Relations among Riparian Vegetation, Channel Incision Processes and Forms, and Large Woody Debris. In: Incised River Channels. S. E. Darby \& A. Simon (eds.).: 219246. John Wiley \& sons, Chichester.

JANSEN, A., A. ROBERTSON, L. THOMPSON \& A. WILSON. 2004. Development and application of a method for the rapid appraisal of riparian condition. River and Riparian Land Management Technical Guideline, 4. Land \& Water Australia, Canberra. 14 pp.

JOHNSON, W. C. 2002. Riparian vegetation diversity along regulated rivers: contributing of novel and relict habitats. Freshwat. Biol., 47(4): 749-760.

JOHNSON, R. R. \& J. F. MCCORMICK. 1978. Strategies for Protection and Management of Floodplain Wetlands and other Riparian Ecosystems. GTR WO-12, USDA Forest Service, Washington D.C. 410 pp.

JOHNSON, R. R., C.D. ZIEBELL, D. R. PATTON, P. F. FLOLLIOTT \& R. H. HAMRE (eds.). 1985. Riparian Ecosystems and their Management: Reconciling Conflicting Uses. USDA Forest Service, GTR RM-120, Fort Collins, Colorado. 523 pp.

JUNK, W. J. 2005. Flood pulsing and the linkages between terrestrial, aquatic and wetland systems. Verh. Internat. Verein. Limnol., 29: 11-38.

JUNK, W.J. , P. B. BAILEY \& R. E. SPARKS. 1989. The Flood Pulse Concept in River-Floodplain Systems. Can. J. Fish Aquat. Sci., Special Publication, 106: 110-127.

KARR, J. R., K. D. FAUSCH, P. L. ANGERMEIER, P. R. YANT \& I. J. SCHLOSSER. 1986. Assessing Biological Integrity in Running Waters. A method and its rationale. Illinois Natural History Survey, Special Publication, 5. 28 pp.

LARA, F., R. GARILLETI, P. RAMÍREZ \& J. M. VARELA. 1996. Estudio de la vegetación de los rios carpetanos de la Cuenca del Jarama. Publ. CEDEX, Madrid. $270 \mathrm{pp}$.

LARA, F., R. GARILLETI \& J.A. CALLEJA. 2004. La vegetación de ribera de la mitad norte española. CEDEX, Mongrafías, 81. Madrid. 536 pp. 
LEOPOLD, L. B. 1973. River channel change with time: an example. Bulletin Geological Society of America, 84: 1845-1860.

LYTLE, D. A. \& D. M. MERRIT. 2004. Hydrologic Regimes and Riparian Forests: A structured population model for cottonwood. Ecology, 85(9): 2493-2503.

LOVELL, S. T. \& W. C. SULLIVAN. 2005. Environmental benefits of conservation buffers in the United States: Evidence, promise and open questions. Agriculture Ecosystems \& Environment, (in press).

MALANSON, G. P. 1993. Riparian Landscapes. Cambridge Studies in Ecology, Cambridge University Press. 296 pp.

MALARD, F., K. TOCKNER, J. J. DOLE-OLIVIER \& J. V. WARD. 2002. A landscape perspective of surface-subsurface hydrological exchanges in river corridors. Freshwat. Biol., 47(4): 621-640.

MONTGOMERY, D. R. 1999. Process domains and the river continuum. Journal of the American Water Resources Association, 35: 397-410.

MUNNE, A., C. SOLA \& N. PRAT. 1998. QBR : Un índice rápido para la evaluación de la calidad de los ecosistemas de ribera. Tecnología del Agua, 175: 20-37.

MUNNE, A., N. PRAT, C. SOLA, N. BONADA \& M. RIERADEVALL. 2003. A simple field method for assessing the ecological quality of riparian habitat in rivers and streams : QBR Index. Aquatic Conservation: Marine and Freshwater Ecosystems, 13: 147-163.

NAIMAN, R. J. (ed.). 1992. Watershed Management. Springer-Verlag, New York. 542 pp.

NAIMAN, R. J. \& R. E. BILBY (eds.). 1998. River Ecology and Management. Springer, New York. 705 pp.

NAIMAN, R. J. \& H. DECAMPS (eds.). 1990. The Ecology and Management of Aquatic-Terrestrial Ecotones. Man and The Biosphere Series, UNESCO, París. 316 pp.

NILSSON, CH. \& K. BERGGREN. 2000. Alterations of Riparian Ecosystems caused by River Regulation. BioScience, 50(9): 783-792.

ODUM, E. P. 1978. Ecological Importance of the Riparian Zone. En: Strategies for Protection and Management of Floodplain Wetlands and other Riparian Ecosystems. R. R. Johnson \& J. F. McCormick (eds.).: 2-5. GTR WO-12, USDA Forest Service, Washington D.C.

OSBORNE, L. L., \& D. A. KOVACIC. 1993. Riparian vegetated buffer strips in water-quality res- toration and stream management. Freshwat. Biol., 29(2): 243-258.

OVERTON, C. K., S. P. WOLLRAB, B. C. ROBERTS \& M. A. RADKO. 1997. R1/R4 (Northern/Intermountain Regions) Fish and Fish Habitat Standard Inventory Procedures Handbook. USDA, INT-GTR-346. 73 pp.

PALMER, M. A., E. S. BERNHARDT, J. D. ALLAN, P. S. LAKE, G. ALEXANDER, S. BROOKS, J. CARR, S. CLAYTON, C. N. DAHM, J. FOLLSTAD SHAH, D. L. GALAT, S. G. LOSS, P. GOODWIN, D. D. HART, B. HASSETT, R. JENKINSON, G. M. KONDOLF, R. LAVE, J. L. MEYER, T. K. O'DONNELL, L. PAGANO \& E. SUDDUTH. 2005. Standars for ecologically succesful river restoration. Journal of Applied Ecology, 42: 208-217.

PETTIT, N. E., R. H. FROEND \& P. M. DAVIES. 2001. Identifying the natural flow regime and the relationship with riparian vegetation for two contrasting western Australian rivers. Regulated Rivers: Research \& Management, 17: 201-215.

PLATTS, W. S., W. F. MEGAHAN \& G. W. MINSHALL. 1987. Methods for evaluating Stream, Riparian and Biotic conditions. USDA, Forest Service. $177 \mathrm{pp}$.

POOLE, G. C. 2002. Fluvial Landscape Ecology: addressing uniqueness within the river discontinuum. Freshwat. Biol., 47(4): 641-660.

RICHARDS, K., J. BRASINGTON \& F. HUGHES. 2002. Geomorphic dynamics of floodplains: ecological implications and a potential modelling strategy. Freshwat. Biol., 47(4): 559-580.

SALO, J., R. KALLIOTA, I. HÄKKINEN, Y. MÄKINEN, P. NIÑÉEMELA, M. PUHAKKA \& P.D. COLEY. 1986. River dynamics and the diversity of Amazon lowland forests. Nature, 322: 254-258.

SCHULTZ, R.C., P. H. WRAY, J. P. COLLETI, T. M. ISENHART, C. A. RODRIGUES \& A. JUCHL. 1997. Stewards of Our Streams: Buffer strip design, establishment and maintenance. Iowa State University, University Extension, PM 1626b. 6 pp.

SEAR, D.A. 1996. The Sediment System and Channel Stability. In: River Channel Restoration. A. Brookes \& F. D. Shields (eds.).: 149-178. John Wiley \& sons, Chichester.

SPACKMAN, S. C. \& J. W. HUGHES. 1995. Assessment of minimum stream corridor width for biological conservation: species richness and distribution along mid-order streams in Vermont, USA. Biological Conservation, 71: 325-332. 
STANFORD, J. A. \& J. V. WARD. 1993. An ecosystem perspective of alluvial rivers: connectivity and the hiporheic corridor. $J$ North Am. Benthol. Soc., 12: 48-60.

STEWARDSON, M. 2005. Hydraulic geometry of stream reaches. Journal of Hydrology, 306: 97-111.

STROMBERG, J. C., R. TILLER \& B. D. RICHTER. 1996. Effects of groundwater decline on riparian vegetation of semiared regions: the San Pedro River, Arizona, USA. Ecological Applications, 6: 113-131.

SUÁREZ, M. L. \& M. R. VIDAL-ABARCA. 2000. Aplicación del índice de calidad del bosque de ribera QBR (Munné et al. 1998) a los cauces fluviales de la Cuenca del río Segura. Tecnología del Agua, 201: 33-45.

SUÁREZ, M. L., M. R. VIDAL-ABARCA, M. SÁNCHEZ-MONTOYA, J. ALBA, M. ÁLVAREZ, J. AVILÉS, N. BONADA, J. CASAS, P. JAIMEZCUÉLLAR, A. MUNNÉ, I. PARDO, N. PRAT, M. RIERADEVALL, J. SALINAS, M. TORO \& S. VIVAS. 2002. Las riberas de los ríos mediterráneos y su calidad: El uso del índice QBR. Limnetica, 21(3-4): 135-148.

TABACCHI, E., A. PLANTY-TABACCI \& O. DÉCAMPS. 1990. Continuity and discontinuity of the riparian vegetation along a fluvial corridor. Landscape Ecology, 5(1): 9-20.

THOMS, M. C. 2003. Flood-plain river ecosystems: lateral connections and the implications of human interference. Geomorphology, 56: 335-349.

THORNE, C. R. 1990. Effects of Vegetation on Riverbank Erosion and Stability. In: Vegetation and Erosion. J. B. Thornes (ed.).: 125-144. John Wiley \& Sons, Chichester.

TOCKNER, K., J. V. WARD, P. J. EDWARDS \& J. KOLLMANN. 2002. Riverine Landscapes: an introduction. Freshwat. Biol., 47(4): 497-500.
VANNOTTE, R. L., G. W. MINSHALL, K. W. CUMMINS, J. R. SEDELL \& C. E. CUSHING. 1980. The river continuum concept. Can. J. Fish. Aquat. Sci., 37: 130-137.

WARD, J. V. 1989. The four-dimensional nature of lotic ecosystems. J. North Am. Benthol. Soc., 8: 2-8.

WARD, J.V., G. BRETSCHKO, M. BRUNKE, D. L. DANIELOPOL, J. GIBERT, T. GONSER \& A.G. HILDREW. 1998. The boundaries of river systems: the metazoan perspective. Freshwat. Biol., 40: 531-569.

WARD, T. A., K. W. TATE \& E. R. ATWILL. 2003. Visual Assessment of Riparian Health. University of California, Rangeland Monitoring Series, ANR Publication 8089, Oakland, California. 23 pp.

WARD, J. V. \& K. TOCKNER. 2001. Biodiversity: towards a unifying theme for river ecology. Freshwat. Biol., 46: 807-819.

WARD, J. V., K. TOCKNER, D. B. ARSCOTT \& C. CLARET. 2002. Riverine landscape diversity. Freshwat. Biol., 47: 517-539.

WARNER, R. E. \& K. M. HENDRIX (eds.). 1984. California Riparian Systems. California University Press, Berkeley. 1035 pp.

WIGINGTON, P. J. \& R. L. BESCHTA. 2000. Riparian Ecology and Management in Multi-Land Use Watersheds. Procs. AWRA's 2000 Summer Specialty Conference, Portland, Oregón. 616 pp.

WINWARD, A. H. 2000. Monitoring the Vegetation Resources in Riparian Areas. USDA, RMRSGTR-47, Ogden, Utah. 49 pp.

ZAMORA-ARROYO, F., P.L. NAGLER, M. BRIGGS，D. RADTKE，H. RODRÍGUEZ，J. GARCÍA, C. VALDÉS, A. HUETE \& E.P. GLENN. 2001. Regeneration of native trees in response to flood releases from the United Status into the delta of the Colorado river, Mexico. Journal of Arid Environments, 49: 49-64. 